\title{
DA EXCEÇÃO AGAMBENIANA À CONSTITUIÇÃO PLANETÁRIA DE FERRAJOLI: DESAFIOS IMPOSTOS PELA PANDEMIA DO NOVO CORONAVÍRUS ÀS CATEGORIAS JURÍDICO-POLIITICAS TRADICIONAIS
}

\author{
FROM THE GIORGIO AGAMBEN'S EXCEPTION TO THE PLANETARY \\ CONSTITUTION OF FERRAJOLI: CHALLENGES IMPOSED BY THE NEW \\ CORONAVIRUS PANDEMIC TO TRADITIONAL LEGAL-POLITICAL CATEGORIES
}

\author{
DE LA EXCEPCIÓN DE GIORGIO AGAMBEN A LA CONSTITUCIÓN \\ PLANETARIA DE FERRAJOLI: DESAFÍOS IMPUESTOS POR LA NUEVA \\ PANDEMIA DE CORONAVIRUS A LAS CATEGORÍAS JURÍDICO-POLÍTICAS \\ TRADICIONALES
}

\begin{abstract}
MAIQUEL ÂNGELO DEZORDI WERMUTH http://orcid.org/0000-0002-7365-5601 / http://lattes.cnpq.br/0354947255136468 / madwermuth@gmail.com Universidade do Vale do Rio dos Sinos - UNISINOS Universidade Regional do Nororeste do Estado do Rio Grande do Sul - UNIJUÍ. São Leopoldo, RS. / Ijuí, RS, Brasil.
\end{abstract}

JosÉ LUIS BOLZAN DE MORAIS http://orcid.org/0000-0002-0959-0954 / http:/ / lattes.cnpq.br/4650999047027866 / bolzan@hotmail.com Faculdade de Direito de Vitória- FDV. Vitória, ES, Brasil.

\begin{abstract}
RESUMO
O artigo propõe-se a fazer uma revisão de alguns dos principais posicionamentos teóricos produzidos até o momento acerca das medidas restritivas de liberdade e do estado de emergência reconhecido em decorrência da pandemia do novo coronavírus, buscando estabelecer um diálogo entre o pensamento de diversos autores que, mesmo a partir de marcos teóricos e ferramentas conceituais diferentes, propõem-se a suscitar reflexões sobre a situação que tem se mostrado enquanto verdadeiro marco divisor de águas na história da humanidade, dada a magnitude das consequências até então mapeadas e do tensionamento de categorias jurídico-políticas tradicionais por ela posta. 0 texto encontra-se dividido em três seções: na primeira, busca-se estabelecer um diálogo entre as perspectivas teóricas de Giorgio Agamben e Slavoj Žižek - as quais versam sobre questão do estabelecimento de um verdadeiro estado de exceção (Agamben) e a retomada/revisitação do conceito de "comunismo" como condição de possibilidade para o enfrentamento à doença (Žižek); na segunda seção apresenta-se a perspectiva de Luigi Ferrajoli acerca da necessidade de construção de uma “Constituição planetária” para o enfrentamento das diferentes crises da contemporaneidade; esta perspectiva é colocada em diálogo, na terceira seção, com a teoria de Delmas-Marty, pensada enquanto condição de possibilidade para dar concretude ao anseio do jurista italiano.
\end{abstract}

Palavras-chave: Coronavírus; pandemia; estado de exceção; constituição planetária; globalização; direito internacional.

\section{ABSTRACT}

The article proposes to make a review of some of the main theoretical positions produced so far about restrictive freedom measures and the state of emergency recognized as a result of the new coronavirus pandemic, seeking to establish a dialogue between the thought of different authors who, even from theoretical frameworks and conceptual 
DA EXCEÇÃO AGAMBENIANA À CONSTITUIÇÃO PLANETÁRIA DE FERRAJOLI: DESAFIOS IMPOSTOS PELA PANDEMIA DO NOVO CORONAVÍRUS ÀS CATEGORIAS JURÍDICO-POLÍTICAS TRADICIONAIS

MAIQUEL ÂNGELO DEZORDI WERMUTH JOSÉ LUIS BOLZAN DE MORAIS

tools differents, aim to raise reflections about the situation that has shown itself as a true watershed in human history, given the magnitude of the consequences hitherto mapped and the tension of traditional legal-political categories for it imposed. The text is divided into three sections: in the first, it seeks to establish a dialogue between the theoretical perspectives of the Giorgio Agamben and Slavoj Žižek - which deal about the question of the establishment of a true state of exception (Agamben) and the resumption/revisit of the concept of "communism" as a condition of possibility for coping with the disease (Žižek); in the second section presents the Luigi Ferrajoli's perspective about of the need of the to build a "planetary Constitution" to face the different contemporary crises; this perspective is placed in dialogue, in the third section, with the theory of Delmas-Marty, thought as a condition of possibility to give concreteness to the aspiration of the Italian jurist.

Keywords: Coronavirus; Pandemic; Exception State; Planetary Constitution; Globalization; International Right.

\section{RESUMEN}

El artículo propone revisar algunas de las principales posiciones teóricas producidas hasta ahora sobre las medidas restrictivas de la libertad y el estado de emergencia reconocido debido a la pandemia del nuevo coronavirus, buscando establecer un diálogo entre los pensamientos de varios autores que, incluso desde diferentes marcos teóricos y herramientas conceptuales, proponen plantear reflexiones sobre la situación que se ha mostrado como un verdadero hito en la historia de la humanidad, dada la magnitud de las consecuencias mapeadas hasta ahora y la tensión de las categorías jurídico-políticas tradicionales puestas por él. El texto está dividido en tres secciones: en la primera, busca establecer un diálogo entre las perspectivas teóricas de Giorgio Agamben y Slavoj Žižek, que abordan la cuestión del establecimiento de un verdadero estado de excepción (Agamben) y la reanudación del concepto de "comunismo" como una condición de posibilidad para hacer frente a la enfermedad (Žižek); la segunda sección presenta la perspectiva de Luigi Ferrajoli sobre la necesidad de construir una "Constitución planetaria" para enfrentar las diferentes crisis contemporáneas; esta perspectiva se sitúa en el diálogo, en la tercera sección, con la teoría de Delmas-Marty, pensada como una condición de posibilidad para dar concreción al deseo del jurista italiano.

Palabras clave: coronavirus; pandemia estado de excepción; constitución planetaria; globalización derecho internacional.

\section{SUMÁRIO}

CONSIDERAÇÕES INICIAIS; 1 DO ESTADO DE EXCEÇÃO AGAMBENIANO AO “COMUNISMO” DE ŽIŽEK; 2 FERRAJOLI E A “CONSTITUIÇÃO PLANETÁRIA": CONDIÇÃO DE POSSIBILIDADE PARA O "COMUM"?; 3 A NECESSIDADE DE COMPATIBILIZAR LIBERDADE E SEGURANÇA; CONSIDERAÇÕES FINAIS: PARA NÃO CONCLUIR...; REFERÊNCIAS.

\section{CONSIDERAÇÕES INICIAIS}

Era carnaval no Brasil. Enquanto festejávamos ou nos limitávamos a discutir a efetiva contribuição das escolas de samba em denunciar as mazelas político-sociais do País, ouvíamos, como um eco distante, falar sobre uma cidade chinesa até então desconhecida da maioria dos brasileiros - Wuhan - na qual se desenvolvia um quadro de alarma social relacionado a uma doença desconhecida, causada por uma nova cepa do coronavírus que logo recebeu nome: COVID-19. Entre nós, as festas terminaram e, no clima da ressaca que caracteriza o retorno à “normalidade" pós-carnaval, fomos surpreendidos com o avanço dos casos de contaminação na Europa - em especial a tragédia italiana, que para além da crise sanitária explicitou uma crise humanitária decorrente da incapacidade de tratamento universal daqueles afetados pelo vírus - 
e, logo mais, aquele eco distante se tornou um retumbar dissonante - seria "histeria"? Não. Trata-se de uma pandemia.

Pandemia. Esta palavra de origem grega que é formada com o prefixo neutro pan e demos, que designa povo, foi utilizada, pioneiramente, por Platão na obra "Das Leis"1. Na obra de Platão, a expressão, utilizada genericamente, designa qualquer fato/acontecimento que possua capacidade de alcançar toda uma população. No campo da medicina, Galeno foi responsável pela utilização da expressão "pandêmica" para designar doenças epidêmicas de grande difusão entre a população ${ }^{2}$. De acordo com estudo realizado por Joffre Marcondes de Rezende $^{3}$, a incorporação definitiva do termo pandemia na léxica da medicina ocorre a partir do século XVIII, sendo que seu registro, na língua francesa, pode ser encontrado no Dictionnaire universel français et latin, de Trévoux, datado de 1771. Na língua portuguesa, a expressão foi dicionarizada como termo médico por Domingos Vieira, em 1873.

Em relação à COVID-19, o reconhecimento de uma pandemia pela Organização Mundial da Saúde (OMS) se deu em coletiva de imprensa realizada no dia 11 de março, quando Tedros Adhanom Ghebreyesus, Diretor-geral da OMS, salientou que a expressão se afigura como uma palavra perigosa em decorrência das diferentes interpretações que pode gerar. No entanto, a magnitude da proliferação da doença passou a justificar a utilização do termo [no momento em que este texto está sendo finalizado - 30 de março de 2020 - o Brasil já registrou 159 mortes em decorrência da doença, tendo 4.579 casos confirmados ${ }^{4}$; a Itália já conta com cerca de 12 mil óbitos e 101.739 casos confirmados da doença ${ }^{5}$; nos Estados Unidos já são 2.800 mortos e mais de 153.000 casos de confirmação da COVID-196].

Como refere Pérez Tapias ${ }^{7}$, trata-se de situação inédita "não apenas pela rápida cadeia de contágios da consequente doença de caráter gripal, mas também pelas medidas sanitárias decididas politicamente para buscar freá-la", isso sem mencionar as "custosas consequências

\footnotetext{
${ }^{1}$ MARCOVECCHIO, E. Dizionario etimológico storico dei íermini mediei. Firenze: Festina Lente, 1993.

${ }^{2}$ LIDDELL, H.G.; SCOTT, R. A greek-english /exicort. 9. ed., Oxford: Claredon Press, 1983.

3 REZENDE, Joffre Marcondes de. Epidemia, endemia, pandemia. Epidemiologia. Revista de Patologia Tropical, vol. 27, n. 1, p 153-155, 1998.

4 Informações disponíveis em: https://g1.globo.com/bemestar/coronavirus/noticia/2020/03/30/brasiltem-159-mortes-e-4579-casos-confirmados-de-coronavirus-diz-ministerio.ghtml . Acesso em: $30 \mathrm{mar} .2020$. ${ }^{5}$ Informações disponíveis em: https://www1.folha.uol.com.br/equilibrioesaude/2020/03/italia-passa-de100000-infectados-por-coronavirus.shtml . Acesso em: 30 mar. 2020.

${ }^{6}$ Informações disponíveis em: https://www1.folha.uol.com.br/equilibrioesaude/2020/03/eua-registrammais-de-153-mil-casos-e-2500-mortes-por-coronavirus.shtml . Acesso em: 30 mar. 2020.

7 PÉREZ TAPIAS, José Antonio. Entre o risco e o medo, a biopolítica em alta. Instituto Humanitas UNISINOS, 17 mar. 2020. Disponível em: http://www.ihu.unisinos.br/78-noticias/597147-entre-o-risco-eo-medo-a-biopolitica-em-alta . Acesso em: 19 mar. 2020.
} 
econômicas e sociais a longo prazo e por todo o planeta." A suposta "ordem econômica internacional", segundo o referido autor, acabou por ser colocada "de cabeça para baixo por um microscópico vírus protagonista de outra face da globalização!" Logo, se "pensávamos que tínhamos tudo sob controle", a pandemia do Covid-19 evidencia que não há controle tecnológico, tampouco econômico: "daí a tremenda cura de humildade que a pandemia desencadeada nos inflige".

Desde então, o mundo se depara com diferentes interpretações e possíveis explicações da recém reconhecida pandemia. Fatalismos, teorias da conspiração, discursos de descrédito e de pânico circulam diariamente pelos principais meios de comunicação do Brasil e do mundo, sobretudo nas novas mídias sociais, escancarando, mais uma vez, a utilização de fake news como instrumento de desinformação, da mesma forma como estas foram e têm sido utilizadas nos processos decisórios dos rumos políticos dos países mundo afora, reconhecidamente desde o caso Cambridge Analytica ${ }^{8}$.

Em face do contexto delineado, o presente artigo propõe-se a fazer uma revisão de alguns dos principais posicionamentos teóricos produzidos até o momento acerca das medidas restritivas de liberdade e do estado de emergência reconhecido em decorrência da pandemia do novo coronavírus, buscando estabelecer um diálogo entre o pensamento de diversos autores que, mesmo a partir de marcos teóricos e ferramentas conceituais diferentes, propõem-se a suscitar reflexões sobre a situação que tem se mostrado enquanto verdadeiro marco divisor de águas na história da humanidade, dada a magnitude das consequências até então mapeadas e do tensionamento de categorias jurídico-políticas tradicionais por ela posta.

Nesse sentido, o texto encontra-se dividido em três seções: na primeira, busca-se estabelecer um diálogo entre as perspectivas teóricas de Giorgio Agamben e Slavoj Žižek - as quais versam sobre questão do estabelecimento de um verdadeiro estado de exceção na esteira das medidas determinadas pelos governos - notadamente o italiano - para a contenção da pandemia (Agamben) e a retomada/revisitação do conceito de “comunismo" como condição de possibilidade para o enfrentamento à doença (Žižek); na segunda seção apresenta-se a perspectiva de Luigi Ferrajoli acerca da necessidade de construção de uma "Constituição planetária" para o enfrentamento das diferentes crises da contemporaneidade que, dado o seu caráter ubíquo em nível global, exigem respostas coordenadas que abandonem as perspectivas da soberania; esta perspectiva é colocada em diálogo, na terceira seção, com a teoria de

8 Um apanhado de notícias sobre o referido caso pode ser consultado em: https://brasil.elpais.com/tag/caso_cambridge_analytica. Aceso em: 22 mar. 2020. 
Delmas-Marty, posta em seu "Aux Quatre Vents du Monde", pensada enquanto condição de possibilidade para dar concretude ao anseio do jurista italiano.

\section{DO ESTADO DE EXCEÇÃO AGAMBENIANO AO “COMUNISMO” DE ŽIŽEK}

Para além das dúvidas e dilemas enfrentados pelas ciências médicas - para cuja compreensão remete-se o leitor à abordagem de Ventura, Aith e Rached ${ }^{10}$-, a pandemia e seu enfrentamento tem produzido muitos questionamentos em termos filosófico-jurídicoeconômicos, os quais apontam para posturas muitas vezes alarmistas, irresponsáveis ou oportunistas, bem como convocam para a proteção e revisão de postulados jurídicos afetados. Veja-se a questão posta entre liberdade e segurança no que concerne aos controles sanitários e de fluxo de pessoas, que colocam em xeque a tradição neoliberal dos apóstolos do capitalismo de cassino ${ }^{11}$, da privatização, do eficientismo etc.

Uma interpretação da situação envolvendo a epidemia no contexto italiano que gerou bastante repercussão foi a adotada por Giorgio Agamben, em artigo publicado por Il Manifesto em 26 de fevereiro de $2020^{12}$, no qual refere que a "invenção" de uma epidemia oferece um "pretexto ideal” para ampliar a utilização de medidas de exceção para além de todo limite, diante do esgotamento do discurso acerca dos riscos do "terrorismo" - discurso este utilizado, como mote, pelo filósofo, para a construção de sua "teoria" do estado de exceção no âmbito do projeto filosófico homo sacer ${ }^{13}$ - tudo, portanto, muito compatível com a construção teórica que vem adotando desde a reapropriação da concepção de estado de exceção em sua obra.

Referido texto, escrito antes do reconhecimento da pandemia pela OMS, levava em consideração, segundo afirma Agamben no próprio texto jornalístico, a declaração oficial do

\footnotetext{
9 DELMAS-MARTY, Mireille. Aux quatre vents du monde: petit guide de navigation sur l'océan de la mondialisation. Paris: Éditions du Seuil, 2016.

10 VENTURA, Deisy de Freitas Lima; AITH, Fernando Mussa Abujamra; RACHED, Danielle Hanna. A emergência do novo coronavírus e a "lei de quarentena" no Brasil. Revista Direito e Práxis, Ahead of print, Rio de Janeiro, 2020. Disponível em: https://www.epublicacoes.uerj.br/index.php/revistaceaju/article/view/49180. Acesso em: 21 mar. 2020.

11 AVELÃS NUNES, António José. 0 estado capitalista em tempos de globalização. 2012. Conferência inaugural do Congresso Internacional sobre "Defesa do Estado e Garantia dos Direitos do Cidadão em Tempos de Crise: os Desafios da Advocacia de Estado - Intercâmbio Brasil/Itália”. Disponível em: https://www.fd.uc.pt/ anunes/pdfs/conf_8.pdf. Acesso em: 19 mar. 2020.

12 AGAMBEN, Giorgio. 0 estado de exceção provocado por uma emergência imotivada. Tradução de Luisa Rabolini. Instituto Humanitas UNISINOS, 26 fev. 2020a. Disponível em: http://www.ihu.unisinos.br/78noticias/596584-o-estado-de-excecao-provocado-por-uma-emergencia-imotivada. Acesso em: 18 mar. 2020.

${ }^{13}$ AGAMBEN, Giorgio. Estado de exceção. Tradução de Iraci Poletti. Rio de Janeiro: Boitempo, 2004.
} 
Conselho Nacional de Pesquisas italiano que não reconhecia a existência de uma epidemia causada pelo novo coronavírus na Itália, salientando que a infecção, diante dos dados epidemiológicos até então levantados, era responsável por ocasionar sintomas leves/moderados, semelhantes a uma gripe, e que em poucos casos poderia produzir o desenvolvimento de uma pneumonia com decurso benigno para a maioria absoluta dos infectados.

Diante dessa afirmação, Agamben questionava os motivos pelos quais a mídia e as autoridades públicas italianas estavam disseminando um discurso de pânico, responsável pelo estabelecimento de um "verdadeiro e próprio estado de exceção, com sérias limitações das movimentações e suspensão do funcionamento normal das condições de vida e de trabalho."14

Para explicar esse comportamento considerado, por ele, "desproporcional", Agamben recorre a dois fatores: a) a crescente tendência de utilização do estado de exceção como técnica de governo - estratégia já analisada pormenorizadamente na obra "Estado de exceção"15; b) a difusão de um "estado de medo" a justificar medidas restritivas de direitos em prol de uma maior segurança cidadã.

Sob esta perspectiva, o filósofo interpretou, naquela oportunidade, o Decreto-lei $n^{\circ} 6$, de 23 de fevereiro de 2020, acerca das “Medidas urgentes para a contenção e gerenciamento da emergência epidemiológica do COVID-19"16 aprovado pelo governo italiano em razão do contexto de aumento das contaminações pelo novo coronavírus como manifestação de uma verdadeira estratégia de militarização, alicerçada em fórmulas vagas e indeterminadas que permitiriam que medidas excepcionais - a exemplo da proibição de afastamento/acesso a municípios ou áreas afetadas, suspensão de manifestações/eventos/reuniões em locais públicos ou privados, suspensão dos serviços educacionais, suspensão dos serviços de abertura ao público de museus e outros institutos e locais culturais, suspensão de todas as viagens educacionais, suspensão de processos de concurso e de atividades de órgãos públicos (exceto em casos de serviços

\footnotetext{
${ }^{14}$ AGAMBEN, Giorgio. 0 estado de exceção provocado por uma emergência imotivada. Tradução de Luisa Rabolini. Instituto Humanitas UNISINOS, 26 fev. 2020a. Disponível em: http://www.ihu.unisinos.br/78noticias/596584-o-estado-de-excecao-provocado-por-uma-emergencia-imotivada. Acesso em: 18 mar. 2020.

${ }^{15}$ AGAMBEN, Giorgio. Estado de exceção. Tradução de Iraci Poletti. Rio de Janeiro: Boitempo, 2004.

16 Texto integral disponível em: https://www.silpcgil.it/articolo/8180-testo_coordinato_del_decretolegge_23_febbraio_2020\%2C_n._6_recante\%3A_«misure_urgenti_in_materia_di_contenimento_e_gestione dell\%27emergenza_epidemiologica_da_covid-19.». Acesso em: 18 mar. 2020. Veja-se que o referido regramento foi editado em final de fevereiro, quando a situação já estava instalada na Itália, sendo ainda desconsiderada a adoção de medidas mais drásticas, como a de lock out, que viriam a ser implementadas em momento posterior, o que gerou críticas de autoridades sanitárias, assim como põe em cena a dificuldade de as democracias liberais conseguirem adequar o discurso da liberdade com aquele da segurança, no caso segurança sanitária, em especial quanto às determinações de restrição de circulação.
} 
essenciais), aplicação da medida de quarentena com vigilância ativa dos indivíduos que tiveram contato próximo com casos confirmados da doença - fossem rapidamente estendidas a todas as regiões do país, o que, na sua leitura, afigurava uma verdadeira desproporção diante de uma doença cujos sintomas eram de uma "simples gripe"17.

Por outro lado, Agamben ${ }^{18}$ também destacou o fato de que forjar um “estado de medo" é uma prática recorrentemente utilizada pelos governos para, por meio da criação de situações de pânico coletivo, legitimar limitações de liberdade. Nesse sentido, uma "epidemia" ofereceria o "pretexto ideal” para essas limitações, configurando "um perverso círculo vicioso", no qual "a limitação da liberdade imposta pelos governos é aceita em nome de um desejo de segurança que foi induzido pelos próprios governos que agora intervêm para satisfazê-lo." Esse modelo se tornou crescente no pós-11 de setembro de 2001, quando o medo do terror induziu algo como que uma permissão à restrição de liberdades em nome de um aparente sentimento de segurança, inclusive com a afetação da privacidade dos cidadãos, a redução das garantias, a construção do “não-cidadão" - transformado em “inimigo". Esta situação levou à construção de um novo sujeito, aquele constituído a partir de uma subjetividade baseada na segurança, nomeado por Hardt e Negri ${ }^{19}$ securitizado.

Em um artigo intitulado "Contagio", publicado no dia em que a OMS reconheceu a pandemia em relação ao novo coronavírus, Agamben ${ }^{20}$ salienta que uma das consequências mais desumanas da disseminação do pânico na Itália por conta da nova doença reside na ideia de contágio, que está na base das medidas excepcionais de emergência adotadas pelo governo. Para ele, ainda mais triste que as limitações de liberdades por meio do Decreto-lei acima referido, é a degeneração das relações humanas que essas medidas podem produzir: “L'altro uomo, chiunque egli sia, anche una persona cara, non dev'essere né avvicinato né toccato e occorre anzi mettere fra noi [...]. Il nostro prossimo è stato abolito." Diante do que chama de “inconsistência ética” das autoridades públicas, o filósofo reflete sobre a possibilidade de que as

17 AGAMBEN, Giorgio. 0 estado de exceção provocado por uma emergência imotivada. Tradução de Luisa Rabolini. Instituto Humanitas UNISINOS, 26 fev. 2020a. Disponível em: http://www.ihu.unisinos.br/78noticias/596584-o-estado-de-excecao-provocado-por-uma-emergencia-imotivada. Acesso em: 18 mar. 2020.

${ }^{18}$ AGAMBEN, Giorgio. O estado de exceção provocado por uma emergência imotivada. Tradução de Luisa Rabolini. Instituto Humanitas UNISINOS, 26 fev. 2020a. Disponível em: http://www.ihu.unisinos.br/78noticias/596584-o-estado-de-excecao-provocado-por-uma-emergencia-imotivada. Acesso em: 18 mar. 2020.

19 HARDT, Michael; NEGRI, Antonio. Multidão: guerra e democracia na Era do Império. Rio de Janeiro: Record, 2005.

20 AGAMBEN, Giorgio. Contagio. Quodlibet, 11 mar. 2020b. Disponível em: https://www.quodlibet.it/giorgio-agamben-contagio. Acesso em: 18 mar. 2020. 
medidas de emergência visem, ao fim e ao cabo, que paremos de nos encontrar, que não mais falemos por razões políticas ou culturais, e que apenas troquemos mensagens digitais, que, enfim, as máquinas substituam todo o contato - contagio - entre os seres humanos.

Em resposta às críticas contra si direcionadas por conta da publicação dos dois textos acima analisados ${ }^{21}$, Agamben ${ }^{22}$ faz alguns esclarecimentos (Chiarimenti) em artigo publicado em 17 de março de 2020. Nele, o filósofo refere que a onda de pânico que paralisa a Itália evidencia que a sociedade contemporânea não acredita em nada mais além da vida nua, salientando que os italianos se dispõem a sacrificar praticamente tudo - condições normais de vida, relações sociais e de trabalho, afetos e até mesmo crenças religiosas e políticas - em face do perigo de adoecer. Ocorre que, na sua perspectiva, a vida nua e o medo de perdê-la não une, mas separa os homens, cegando-os, transformando os “outros" em algo a ser evitado/afastado.

Em face deste contexto o filósofo questiona sobre as transformações nas relações humanas em um cenário como o da sociedade italiana nos últimos dias, e reflete sobre o que é, em essência, uma sociedade que não possui outro valor para além da sobrevivência. Para Agamben $^{23}$, o contexto de medidas de emergência no combate ao novo coronavírus na Itália é prova de que os seres humanos se habituaram a viver em condições de crise perene, e não percebem que suas vidas foram reduzidas a uma condição exclusivamente biológica, alijada das dimensões sociais, políticas, humanas e emocionais. Para o autor, "una società che vive in un perenne stato di emergenza non può essere una società libera" e, em verdade, "viviamo in una società che ha sacrificato la libertà alle cosiddette 'ragioni di sicurezza' e si è condannata per questo a vivere in un perenne stato di paura e di insicurezza." Este estado de medo e insegurança perene é potenciado, no caso do coronavírus, pelo fato de que o perigo - o inimigo está dentro de nós mesmos. Trata-se, portanto, de um contexto de guerra contra um inimigo que - invisível - se esconde dentro de outros homens e que poderá deixar - assim como as guerras já vivenciadas pela humanidade - rastros nocivos que afetarão nosso futuro.

Todavia, a leitura agambeniana tem sofrido diversos questionamentos, como já anotado antes, sobretudo desde a perspectiva que adota quanto à concepção de biopolítica,

\footnotetext{
${ }^{21}$ A resposta agambeniana, parece, é voltada às críticas elaboradas por Paolo Flores d'Arcais no artigo intitulado "Filosofia e virus: le farneticazioni di Giorgio Agamben", disponível em: http://temi.repubblica.it/micromega-online/filosofia-e-virus-le-farneticazioni-di-giorgio-

agamben/?fbclid=IwAR1zk7V9K4NJQ ZaDZ5ajGcuCCjZBANu2Tfc9KQhYT5YuWKt8S4HLtTdA-g. Acesso em: 18 mar. 2020.

22 AGAMBEN, Giorgio. Chiarimenti. Quodlibet, 17 mar. 2020c. Disponível em: https://www.quodlibet.it/giorgio-agamben-chiarimenti . Acesso em: 18 mar. 2020.

23 AGAMBEN, Giorgio. Chiarimenti. Quodlibet, 17 mar. 2020c. Disponível em: https://www.quodlibet.it/giorgio-agamben-chiarimenti . Acesso em: 18 mar. 2020.
} 
compreendida em termos de uma nova espécie de totalitarismo ligado à fórmula "estado de exceção" que recupera, como também já indicado neste mesmo trabalho, com um viés catastrófico no qual as novas formas de capitalismo "estão sempre capturando e totalizando uma mistificada liberdade preexistente, anterior à chegada do biopoder", como aponta Bruno Cava Rodrigues $^{24}$, incorporando à análise da pandemia uma falsa consciência baseada em tais fundamentos. Com isso, as estratégias políticas - no sentido de políticas públicas de enfrentamento da emergência sanitária - são percebidas como mais um exemplo deste biopoder totalitário e excludente.

Ora, não parece ser esta - de Agamben - uma verdade definitiva em torno à ideia de biopolítica, podendo-se repensá-la sob o viés de ajustes que, ao contrário do sugerido por este filósofo italiano, contribuem para a autonomização ou para a reconstrução de vínculos sociais, até mesmo disruptivos. O enfrentamento da crise sanitária, ao contrário de produzir o distanciamento agambeniano, pode, nesta perspectiva produzir novos vínculos ou a reconstrução de laços perdidos na "normalidade" neoliberal. Como assevera Domenico de Masi" a crise histórica posta pelo novo coronavírus, marcada pela morte e pela tragédia, "se por um lado nos leva à recessão, por outro nos lembra que, para evitar uma crise irreparável, em vez de políticas de austeridade, é preferível dar lugar aos investimentos públicos maciços e “open-ended”, ainda que isso leve ao déficit público."

Como sugerido por Pérez Tapias ${ }^{26}$ a pandemia de Covid-19 pode representar uma "nova versão da correlação bidirecional global-local", o que "pode ser feita de maneira frutiferamente criativa ou regressivamente, pretendendo imunização com base em uma comunitarização mais fechada." Assim, da "globalização da doença" poder-se-ia sair para uma "globalização da salubridade", apontando para um sentido comum em relação a bens comuns - aqueles que todos temos direito a aceder igualmente, irredutíveis à sua apreensão mercadológica ${ }^{27} 28$.

\footnotetext{
24 RODRIGUES, Bruno Cava. Democracia biopolítica. Instituto Humanitas UNISINOS, 15 mar. 2020. Disponível em: http://www.ihu.unisinos.br/597085-democracia-biopolitica. Acesso em: 19 mar. 2020.

25 DE MASI, Domenico. Coronavírus anuncia revolução no modo de vida que conhecemos. Folha de São Paulo, 22 mar. 2020. Disponível em: https://www1.folha.uol.com.br/ilustrissima/2020/03/coronavirusanuncia-revolucao-no-modo-de-vida-que-conhecemos.shtml . Acesso em: 22 mar. 2020.

26 PÉREZ TAPIAS, José Antonio. Entre o risco e o medo, a biopolítica em alta. Instituto Humanitas UNISINOS, 17 mar. 2020. Disponível em: http://www.ihu.unisinos.br/78-noticias/597147-entre-o-risco-eo-medo-a-biopolitica-em-alta. Acesso em: 19 mar. 2020.

27 FERRAJOLI, Luigi. Por uma teoria dos direitos e dos bens fundamentais. Porto Alegre: Livraria do Advogado. 2011 (Coleção Estado e Constituição. BOLZAN DE MORAIS, Jose Luis (Dir.). n. 11.).

${ }^{28}$ Como salienta Ferrajoli: "Chamarei por outro lado de bens fundamentais os bens cuja acessibilidade é garantida a todos e a cada um porque objeto de outros tantos direitos fundamentais e que por isso, da mesma forma que estes, são subtraídos à lógica do mercado: como o ar, a água e outros bens do
} 
Ou seja, ao contrário de vermos no tratamento da pandemia um afastamento e isolamento ainda maior, as restrições impostas pelas políticas de combate à doença, pela imposição do nomeado isolamento social para retardar a propagação do vírus, leva à viabilização do tratamento daqueles que necessitam de hospitalização, bem como ao compromisso social de proteção mútua, além de expor drasticamente os resultados das políticas neoliberais de privatização, flexibilização e contingenciamento de investimentos em políticas sociais de saúde.

Com efeito, os argumentos que justificam as restrições à liberdade dos cidadãos em nome da proteção à vida, somam-se aos argumentos que dizem respeito à capacidade de resposta do sistema de saúde à pandemia, sistema esse que foi bastante prejudicado pelos cortes que sofreu nos últimos anos em países nos quais - a exemplo da Itália e da Espanha - a direita aplica, sem pejo, seu programa neoliberal. Nesse sentido, o contexto atual relacionado ao novo coronavírus coloca em cena o preço - não apenas monetário - que se paga pela submissão da saúde - ou seja, as exigências de proteção à saúde e atenção à doença - a critérios de mercado que primam pelo privado em detrimento do público. Trata-se, em última análise, de reavaliar a relação antagônica entre mercado e Estado, a fim de se diminuir a primazia absoluta do primeiro diante da constatação de que, na realidade, necessitamos do segundo ${ }^{29}$.

As análises de Slavoj Žižek ${ }^{30}$ acerca das críticas liberais e da esquerda àquilo que denomina de "sonho erótico" do totalitarismo - representado pelo bloqueio total da Itália questionam a suposta criação deliberada de um clima de pânico e alarma social por parte das instituições governamentais e do mercado, uma vez que essa difusão do medo coloca em xeque a própria capacidade dessas instituições em efetivamente contornarem o contexto de crise. Diante disso, o filósofo esloveno questiona se seria, realmente, do interesse do capital, bem como do poder estatal, o desencadeamento de uma crise econômica global com a finalidade - redentora de revigorar seu reinado.

patrimônio ecológico da humanidade e, ainda, os órgãos do corpo humano, os fármacos considerados "essenciais" ou "salva-vidas"ou similares." FERRAJOLI, Luigi. Por uma teoria dos direitos e dos bens fundamentais. Porto Alegre: Livraria do Advogado. 2011 (Coleção Estado e Constituição. BOLZAN DE MORAIS, Jose Luis (Dir.). n. 11.), p. 54.

29 PÉREZ TAPIAS, José Antonio. Entre o risco e o medo, a biopolítica em alta. Instituto Humanitas UNISINOS, 17 mar. 2020. Disponível em: http://www.ihu.unisinos.br/78-noticias/597147-entre-o-risco-eo-medo-a-biopolitica-em-alta. Acesso em: 19 mar. 2020.

30 ŽIŽEK, Slavoj. Monitorar e punir? Sim, por favor! Tradução de Leonardo Mendonça. Tradutores proletários, 16 mar. 2020. https: / / tradutoresproletarios.wordpress.com/2020/03/17/zizek-monitorar-e-punir-sim-por-favor. Acesso em: 18 mar. 2020. 
O fato, segundo Žižek ${ }^{31}$, é que essa interpretação dos fatos não possui o condão de fazer desaparecer a realidade da ameaça posta em cena no contexto global pelo novo coronavírus. $\mathrm{E}$ pondera que "a ameaça de infecção viral também deu um tremendo impulso a novas formas de solidariedade local e global, além de deixar clara a necessidade de controle sobre o próprio poder." Nesse sentido, ele destaca que medidas destinadas ao controle de uma epidemia não podem se reduzir de modo automático ao paradigma foucaultiano de vigilância e controle.

O que Žižek ${ }^{32}$ aponta como preocupante é que essas medidas sejam aplicadas de modo a não funcionar para efetivamente conter a proliferação da doença, ao passo que autoridades públicas manipularão e ocultarão fatos/dados. 0 contexto que se coloca, para o esloveno, está distante da perspectiva da extrema direita - à la Trump, que perspectiva o cenário pela via da conspiração - e da esquerda - que reitera discursos de xenofobia e controle social. Tampouco é possível enfrentar o contexto da pandemia por meio de discursos de pânico/fatalistas. 0 que se evidencia, ao fim e ao cabo, é um paradoxo: “não apertar as mãos e ficar isolado quando necessário é a forma atual de solidariedade", a qual pode implicar, inclusive, "um novo impulso à vida do comunismo".

Para justificar o referido "novo impulso comunista", Žižek ${ }^{33}$ recorre ao apelo do Diretorgeral da OMS, Tedros Adhanom Ghebreyesus, datada de 5 de março de 2020, no sentido de que o combate exitoso à propagação do vírus passa pelo compromisso político, uma vez que uma pandemia somente pode ser enfrentada a partir de uma abordagem coletiva, coordenada e abrangente, a qual precisa necessariamente envolver todo o mecanismo do governo ${ }^{34}$. Para Žižek, a abordagem abrangente proposta pela OMS “deve ir muito além da maquinaria de governos isolados", a fim de que possa "abranger a mobilização local de pessoas fora do controle estatal, bem como coordenação e colaboração internacionais fortes e eficientes". Com efeito, "se milhares forem hospitalizados por problemas respiratórios, será necessário um número muito

31 ŽlžEK, Slavoj. Monitorar e punir? Sim, por favor! Tradução de Leonardo Mendonça. Tradutores proletários, 162 mar. $2020 . \quad$ Disponível https://tradutoresproletarios.wordpress.com/2020/03/17/zizek-monitorar-e-punir-sim-por-favor . Acesso em: 18 mar. 2020.

32 ŽlŽEK, Slavoj. Monitorar e punir? Sim, por favor! Tradução de Leonardo Mendonça. Tradutores proletários, 162020.2 mar. 202 em: https://tradutoresproletarios.wordpress.com/2020/03/17/zizek-monitorar-e-punir-sim-por-favor. Acesso em: 18 mar. 2020.

33 ŽlŽEK, Slavoj. Monitorar e punir? Sim, por favor! Tradução de Leonardo Mendonça. Tradutores proletários, 162 mar. $2020 . \quad$ Disponível https://tradutoresproletarios.wordpress.com/2020/03/17/zizek-monitorar-e-punir-sim-por-favor. Acesso em: 18 mar. 2020.

34 Reportagem sobre o apelo do Diretor-geral da OMS mencionado por Žižek pode ser consultada em: https://news.un.org/pt/story/2020/03/1706321. Acesso em: 18 mar. 2020. 
maior de máquinas respiratórias e, para obtê-las, o estado deve intervir diretamente da mesma maneira que intervém em condições de guerra quando milhares de armas são necessárias”. Em um contexto tal, o Estado “deve contar com a cooperação de outros estados. Como em uma campanha militar, as informações devem ser compartilhadas e os planos totalmente coordenados."

É isso que Žižek ${ }^{35}$ propõe como conteúdo semântico do que denomina "comunismo necessário", ao constatar que a pandemia do coronavírus "não sinaliza apenas o limite da globalização do mercado, mas também o limite ainda mais fatal do populismo nacionalista, que insiste na soberania do Estado." E arremata: "a presente crise demonstra claramente como a solidariedade e a cooperação globais são do interesse da sobrevivência de cada um de nós, que é a única coisa racionalmente egoísta a se fazer."

Nesse sentido, “a globalização da salubridade” referida por Pérez Tapias ${ }^{36}$ dialoga com a ideia de "comunismo" proposta por Žižek ${ }^{37}$, na medida em que “toca em cheio as exigíveis condições da vida digna para todos", o que "implica o combate firme contra as desigualdades, dado que estas impedem de fato que, em diferentes escalas nacional e internacional, os objetivos de saúde pública possam ser alcançados." Com isso, ressurgem no debate ético e político "a noção de bem comum, correlacionada com o que é exigível por razões de justiça." 38

Descortina-se, assim, "uma via de redescoberta da fraternidade [...] que é de qualquer forma necessária para que a biopolítica seja verdadeiramente democrática"; trata-se, em outras palavras de fazer com que "a democracia se conjugue como biopolítica, em que a vida seja bem comum que todos cuidamos, também, obviamente, por amor à vida de cada um."39

\footnotetext{
35 ŽlŽEK, Slavoj. Monitorar e punir? Sim, por favor! Tradução de Leonardo Mendonça. Tradutores proletários, 162 mar. 2020.2 Disponível https://tradutoresproletarios.wordpress.com/2020/03/17/zizek-monitorar-e-punir-sim-por-favor . Acesso em: 18 mar. 2020.

36 PÉREZ TAPIAS, José Antonio. Entre o risco e o medo, a biopolítica em alta. Instituto Humanitas UNISINOS, 17 mar. 2020. Disponível em: http://www.ihu.unisinos.br/78-noticias/597147-entre-o-risco-eo-medo-a-biopolitica-em-alta. Acesso em: 19 mar. 2020.

37 ŽlŽEK, Slavoj. Monitorar e punir? Sim, por favor! Tradução de Leonardo Mendonça. Tradutores proletários, 162 mar. 2020.2 Disponível https://tradutoresproletarios.wordpress.com/2020/03/17/zizek-monitorar-e-punir-sim-por-favor. Acesso em: 18 mar. 2020.

38 PÉREZ TAPIAS, José Antonio. Entre o risco e o medo, a biopolítica em alta. Instituto Humanitas UNISINOS, 17 mar. 2020. Disponível em: http://www.ihu.unisinos.br/78-noticias/597147-entre-o-risco-eo-medo-a-biopolitica-em-alta . Acesso em: 19 mar. 2020.

39 PÉREZ TAPIAS, José Antonio. Entre o risco e o medo, a biopolítica em alta. Instituto Humanitas UNISINOS, 17 mar. 2020. Disponível em: http://www.ihu.unisinos.br/78-noticias/597147-entre-o-risco-eo-medo-a-biopolitica-em-alta . Acesso em: 19 mar. 2020.
} 


\section{FERRAJOLI E A “CONSTITUIÇÃO PLANETÁRIA”: CONDIÇÃO DE POSSIBILIDADE PARA O “COMUM"?}

A perspectiva de Slavoj Žižek acima analisada encontra eco em texto recentemente publicado na Revista Time por Yuval Noah Harari ${ }^{40}$ em face do contexto desencadeado pela pandemia do Covid-19. Para o israelense,

we are used to thinking about health in national terms, but providing better healthcare for Iranians and Chinese helps protect Israelis and Americans too from epidemics. This simple truth should be obvious to everyone, but unfortunately it escapes even some of the most important people in the world.

De acordo com a perspectiva de Harari ${ }^{41}$, as crises globais contemporâneas - dentre as quais está a pandemia do Covid-19 - podem ser atribuídas à falta de confiança entre os seres humanos. E, para que uma epidemia seja efetivamente arrostada, é fundamental que a cidadania confie nos especialistas, nos cientistas, nas autoridades públicas. Além disso, os países precisam de confiança recíproca. Ocorre que "over the last few years, irresponsible politicians have deliberately undermined trust in science, in public authorities and in international cooperation." Isso resultou na atual crise, marcada pelo fato de ser absolutamente desprovida da figura de líderes globais com capacidade de inspirar, organizar e também financiar uma resposta global minimamente coordenada. Como resultado, o sistema internacional passa a ser marcado pela xenofobia e pela desconfiança, além do isolacionismo. Ocorre que sem solidariedade global não será possível conter a pandemia.

Portanto, a luta crucial em face da pandemia do novo coronavírus ocorre intra humanidade:

If this epidemic results in greater disunity and mistrust among humans, it will be the virus's greatest victory. When humans squabble - viruses double. In contrast,

\footnotetext{
${ }^{40}$ HARARI, Yuval Noah. In the Battle Against Coronavirus, Humanity Lacks Leadership. Time, 15 mar. 2020. Disponível em: https://time.com/5803225/yuval-noah-harari-coronavirus-humanity-leadership. Acesso em: 20 mar. 2020.

${ }^{41}$ HARARI, Yuval Noah. In the Battle Against Coronavirus, Humanity Lacks Leadership. Time, 15 mar. 2020. Disponível em: https://time.com/5803225/yuval-noah-harari-coronavirus-humanity-leadership. Acesso em: 20 mar. 2020.
} 
if the epidemic results in closer global cooperation, it will be a victory not only against the coronavirus, but against all future pathogens ${ }^{42}$.

É exatamente neste ponto que se estabelece uma relação com a perspectiva de Luigi Ferrajoli $^{43}$, para quem a pandemia do novo coronavírus confirma a necessidade e a urgência de consolidação de um "constitucionalismo planetário", nos termos do que foi proposto e promovido no âmbito da denominada escola "Constituinte Terra". Essa ideia parte do pressuposto de que crises globais - a exemplo das questões ambientais e, recentemente, a pandemia do Covid-19 - exigem respostas globais que tenham a mesma dimensão e eficácia. Como salienta La Valle ${ }^{44}$, são necessários homens e mulheres, independentemente de onde habitem, mas que, juntos, ajam "como um novo sujeito político operante no mundo, que tomem partido pela Terra e se organizem e atuem para que a Terra seja salva e a história continue.”

Nesse sentido é que, recentemente, na cidade de Messina, na Itália, foi fundada uma escola responsável por elaborar e propagar essa urgência, promovendo, concomitantemente, um instrumento idôneo para efetivá-la. Este instrumento, denominado "Constituição da Terra", deriva do constitucionalismo universal embrionário representado pelo sistema onusiano. No entanto, esse sistema é desprovido de institutos de garantia, suportes públicos e leis de implementação, razão pela qual "uma Constituição - não um governo, nem um Leviatã mundial pode ser o programa inédito, mas decisivo, desse gesto de tomar partido pela Terra". ${ }^{45}$

A proposta “Constituição da Terra", na ótica de Ferrajoli4 deve prever "garantias e instituições à altura dos desafios globais e da proteção da vida de todos." Com isso, se evitariam medidas esparsas como aquelas que têm sido adotadas pelos diferentes países Europeus em face da pandemia, que perpassam por diferentes graus de rigor, permitindo um verdadeiro contraste

\footnotetext{
42 HARARI, Yuval Noah. In the Battle Against Coronavirus, Humanity Lacks Leadership. Time, 15 mar. 2020. Disponível em: https://time.com/5803225/yuval-noah-harari-coronavirus-humanity-leadership. Acesso em: 20 mar. 2020.

43 FERRAJOLI, Luigi. O vírus põe a globalização de joelhos. Tradução de Moisés Sbardelotto. Instituto Humanitas UNISINOS, 18 mar. 2020. Disponível em: http://www.ihu.unisinos.br/78-noticias/597204-ovirus-poe-a-globalizacao-de-joelhos-artigo-de-luigi-ferrajoli. Acesso em: 19 mar. 2020.

44 LA VALLE, Raniero. Por uma escola e uma constituição da Terra. Tradução de Moisés Sbardelotto. Instituto Humanitas UNISINOS, 18 dez. 2019. Disponível em: http://www.ihu.unisinos.br/595259. Acesso em: 19 mar. 2020.

45 LA VALLE, Raniero. Por uma escola e uma constituição da Terra. Tradução de Moisés Sbardelotto. Instituto Humanitas UNISINOS, 18 dez. 2019. Disponível em: http://www.ihu.unisinos.br/595259 . Acesso em: 19 mar. 2020.

46 FERRAJOLI, Luigi. O vírus põe a globalização de joelhos. Tradução de Moisés Sbardelotto. Instituto Humanitas UNISINOS, 18 mar. 2020. Disponível em: http://www.ihu.unisinos.br/78-noticias/597204-ovirus-poe-a-globalizacao-de-joelhos-artigo-de-luigi-ferrajoli . Acesso em: 19 mar. 2020.
} 
DA EXCEÇÃO AGAMBENIANA À CONSTITUIÇÃO PLANETÁRIA DE FERRAJOLI: DESAFIOS IMPOSTOS PELA PANDEMIA DO NOVO CORONAVÍRUS ÀS CATEGORIAS JURÍDICO-POLÍTICAS TRADICIONAIS

MAIQUEL ÂNGELO DEZORDI WERMUTH JOSÉ LUIS BOLZAN DE MORAIS

entre as medidas já tomadas em solo espanhol e italiano e aquelas determinadas em território francês e alemão.

Ao tratar sobre o papel da OMS, Ferrajoli ${ }^{47}$ salienta que a Organização, mesmo diante do seu relevante papel no cenário internacional, ainda não possui meios sequer de viabilizar que países pobres tenham acesso àqueles 460 medicamentos que ela mesma - a OMS - estabeleceu, há 40 anos, que deveriam ser acessíveis a todos, e cuja ausência é responsável por mais de 8 milhões de mortes todos os anos. Assim, na medida em que a pandemia de Covid-19 afeta a todos, ricos e pobres indistintamente ${ }^{48}$, abre-se uma oportunidade para que a OMS efetivamente seja uma instituição de garantia global da saúde, "dotada dos poderes e dos meios econômicos necessários para enfrentar a crise com medidas racionais e adequadas", as quais não podem ser "condicionadas por interesses políticos ou econômicos contingentes, mas voltadas a garantir a vida de todos os seres humanos simplesmente por serem quem são."

A perspectiva do jurista italiano, aqui, se coaduna com a postura de Andre-Noël Roth ${ }^{49}$ no sentido de que o Estado Nacional já não possui mais capacidade de impor soluções aos problemas socioeconômicos atuais, seja de forma autoritária, seja de forma negociada com os principais atores sociopolíticos nacionais, o que permite falar no surgimento de um neofeudalismo:

sem uma instituição legítima, capaz de monopolizar um poder de coação jurídica efetiva ao nível internacional, são as empresas transnacionais que vão promulgando o quadro jurídico, em conformidade com seus interesses, a partir do qual dar-se-á a regulação social. Isso significa a emergência de uma forma de neofeudalismo onde as normas de regulação de um setor econômico estão definidas por empresas comerciais dominantes no setor. 0 conteúdo das regras negociadas na periferia limitar-se-ia a um 'ajuste de detalhes', não podendo

47 FERRAJOLI, Luigi. O vírus põe a globalização de joelhos. Tradução de Moisés Sbardelotto. Instituto Humanitas UNISINOS, 18 mar. 2020. Disponível em: http://www.ihu.unisinos.br/78-noticias/597204-ovirus-poe-a-globalizacao-de-joelhos-artigo-de-luigi-ferrajoli. Acesso em: 19 mar. 2020.

${ }^{48} \dot{E}$ importante ressaltar, quanto a este suposto caráter "democrático" da pandemia, particularmente em realidades sociais como a brasileira, que, em realidade, "não tem nada de democrático na doença, ela vai ser sempre sentida de forma diferente a depender do número de pessoas e essa doença é mais letal entre pessoas vulneráveis. Precisamos considerar quem é que tem direito aos bens da vida como água potável, saneamento básico, moradia decente, educação, trabalho. Esses determinantes sociais chamam a atenção para o fato de que a saúde é determinada por muitos fatores pelos quais vamos ter grupos mais ou menos suscetíveis. [...] Não é que o rico não adoeça e não morra, mas até morrer tudo é diferente. 0 tipo de doença, a incidência da doença, como vivi essa doença, como a doença e a minha morte impactam na minha família. A única igualdade é a morte em si e isso não queremos, o resto é tudo desigual." VENTURA, Deisy de Freitas Lima. "Temos que ir pelo caminho de grande investimento público para a proteção das pessoas". 0 Povo on line, 18 mar. 2020. Disponível em: https://www.opovo.com.br/coronavirus/2020/03/18/temos-que-ir-pelo-caminho-de-grande-investimentopublico-para-a-protecao-das-pessoas.html. Acesso em: 21 mar. 2020.

49 ROTH, André-Noël. O Direito em crise: fim do Estado Moderno? In. FARIA, José Eduardo. Direito e globalização econômica: implicações e perspectivas. São Paulo: Malheiros, p. 26, 2010. 
DA EXCEÇÃO AGAMBENIANA À CONSTITUIÇÃO PLANETÁRIA DE FERRAJOLI: DESAFIOS IMPOSTOS PELA PANDEMIA DO NOVO CORONAVÍRUS ÀS CATEGORIAS JURÍDICO-POLÍTICAS TRADICIONAIS

MAIQUEL ÂNGELO DEZORDI WERMUTH JOSÉ LUIS BOLZAN DE MORAIS

ultrapassar o quadro geral da regulação fixado a um nível superior e percebido, pelos níveis de negociações inferiores, como uma realidade insuperável. Com efeito, a capacidade de perceber uma situação como injusta, base da luta em favor de uma maior emancipação, depende em grande parte da posição ocupada dentro do espaço social.

A partir desse cenário, Ferrajoli mostra-se coerente com o projeto que tem traçado para o futuro do constitucionalismo, uma vez superado o paradigma legislativo. Para ele, a alternativa às crises globais radica no desenvolvimento de um constitucionalismo supranacional com idoneidade para o enfrentamento e a solução de problemas globais. Nesse sentido, como já existe uma constituição embrionária de caráter global - representada pela ONU - bastaria estabelecer as normas para conferir efetividade às suas garantias. Em suma, o projeto garantista de Ferrajoli requer a criação de instituições de garantias de direitos de caráter planetário ${ }^{50}$.

As condições para o salto civilizacional que a realização de um constitucionalismo global e uma esfera pública planetária requerem - na ótica de Ferrajoli ${ }^{51}$ - já existem, não apenas no campo institucional - e aqui o autor menciona, como exemplos, os arts. $168^{52}$ e $222^{53}$ do Tratado sobre o Funcionamento da União Europeia - mas também no campo social e cultural. Dentre os vários efeitos da pandemia, Ferrajoli ${ }^{54}$ destaca: a) o surgimento de "uma reavaliação da esfera

${ }^{50}$ FERRAJOLI, Luigi. A democracia através dos direitos: o constitucionalismo garantista como modelo téorico e como projeto político. Tradução de Alexander Araújo de Souza e outros. São Paulo: Revista dos Tribunais, 2015.

51 FERRAJOLI, Luigi. O vírus põe a globalização de joelhos. Tradução de Moisés Sbardelotto. Instituto Humanitas UNISINOS, 18 mar. 2020. Disponível em: <http://www.ihu.unisinos.br/78-noticias/597204-ovirus-poe-a-globalizacao-de-joelhos-artigo-de-luigi-ferrajoli>. Acesso em: 19 mar. 2020.

52 Referido artigo dispõe, no seu apartado 1, que "na definição e execução de todas as políticas e ações da União será assegurado um elevado nível de proteção da saúde", sendo que o apartado 2 preconiza que "a União incentivará a cooperação entre os Estados-Membros" nos domínios relacionados à proteção da saúde, "apoiando, se necessário, a sua ação" e incentivando "a cooperação entre os Estados-Membros a fim de aumentar a complementaridade dos seus serviços de saúde nas regiões fronteiriças." Já o apartado 5 estabelece que "o Parlamento Europeu e o Conselho, deliberando de acordo com o processo legislativo ordinário, e após consulta ao Comité Económico e Social e ao Comité das Regiões, também podem adotar medidas de incentivo destinadas a proteger e melhorar a saúde humana, e nomeadamente a lutar contra os grandes flagelos transfronteiriços, medidas relativas à vigilância das ameaças graves para a saúde com dimensão transfronteiriça [...]." Texto integral disponível em: https://eurlex.europa.eu/resource.html?uri=cellar:9e8d52e1-2c70-11e6-b497-

01aa75ed71a1.0019.01/DOC_3\&format=PDF. Acesso em: 19 mar. 2020.

${ }^{53}$ Ao instituir "cláusulas de solidariedade", o art. 222, em seu apartado 1, dispõe que "a União e os seus Estados-Membros atuarão em conjunto, num espírito de solidariedade, se um Estado-Membro for alvo de um ataque terrorista ou vítima de uma catástrofe natural ou de origem humana." Texto integral disponível em: $\quad$ https: / / eur-lex.europa.eu/resource.html?uri=cellar:9e8d52e1-2c70-11e6-b49701aa75ed71a1.0019.01/DOC_3\&format=PDF. Acesso em: 19 mar. 2020.

54 FERRAJOLI, Luigi. 0 vírus põe a globalização de joelhos. Tradução de Moisés Sbardelotto. Instituto Humanitas UNISINOS, 18 mar. 2020. Disponível em: http://www.ihu.unisinos.br/78-noticias/597204-ovirus-poe-a-globalizacao-de-joelhos-artigo-de-luigi-ferrajoli . Acesso em: 19 mar. 2020. 
pública no senso comum”; b) "uma reafirmação do primado do Estado em relação às Regiões em termos de saúde"; c) "o desenvolvimento - depois de anos de ódio, de racismo e de sectarismos - de um senso extraordinário e inesperado de solidariedade entre as pessoas e entre os povos." Esse sentimento de solidariedade, para o jurista italiano, se manifesta nas ajudas provenientes da China, no entoar de canções comuns, nas manifestações de afeto e gratidão nas sacadas em relação aos profissionais da saúde, entre outros, o que poderia, acrescentamos nós, fazer ressignificar o projeto de Estado Social, em uma versão pós-liberal.

Em suma, ela se manifesta "na percepção de que somos um único povo da Terra, reunido pela condição comum em que todos vivemos.” Em razão disso, Ferrajoli ${ }^{55}$ aposta que, a partir da tragédia suscitada pela pandemia do novo coronavírus, seja possível florescer "uma consciência geral voltada ao nosso destino comum, que, por isso, requer um sistema comum de garantia dos nossos direitos e da nossa convivência pacífica e solidária”. Na esteira do pensamento de Ferrajoli, De Masi ${ }^{56}$ destaca que, a partir da situação de emergência sanitária posta pelo novo coronavírus, "talvez tenhamos aprendido que o caso agora é de vida ou morte e que ninguém pode enfrentar sozinho um vírus tão ardiloso e potente", razão pela qual "são necessários recursos, inteligências, competências, ações e instituições coletivas. Coordenação e coesão geral." Isso implica o estabelecimento de uma "cabine de comando", formada por "um governo competente que tenha autoridade, uma equipe formada por um vértice político de grande inteligência e apoiada pelos máximos representantes das ciências médicas, da economia, da sociologia, da psicologia social e da comunicação."

Há tempos, reconheça-se, Ferrajoli vem chamando a atenção para uma "nova dimensão do constitucionalismo e do garantismo". Como alerta, trata-se de "um constitucionalismo e um garantismo a longo prazo, além de global, para além da lógica individualista dos direitos e da miopia e do estreito localismo da política das democracias nacionais." 57 Identificando as circunstâncias contemporâneos do fenômeno complexo das relações entre poder e política, Ferrajoli já propunha a necessidade de se pensar em um constitucionalismo de direito privado que se colocasse supra-ordenadamente aos poderes econômicos, bem como ao poder político,

${ }^{55}$ FERRAJOLI, Luigi. 0 vírus põe a globalização de joelhos. Tradução de Moisés Sbardelotto. Instituto Humanitas UNISINOS, 18 mar. 2020. Disponível em: http://www.ihu.unisinos.br/78-noticias/597204-ovirus-poe-a-globalizacao-de-joelhos-artigo-de-luigi-ferrajoli . Acesso em: 19 mar. 2020.

${ }^{56}$ DE MASI, Domenico. Coronavírus anuncia revolução no modo de vida que conhecemos. Folha de São Paulo, 22 mar. 2020. Disponivel em: https://www1.folha.uol.com.br/ilustrissima/2020/03/coronavirusanuncia-revolucao-no-modo-de-vida-que-conhecemos.shtml . Acesso em: 22 mar. 2020.

${ }^{57}$ FERRAJOLI, Luigi. Por uma teoria dos direitos e dos bens fundamentais. Porto Alegre: Livraria do Advogado. 2011 (Coleção Estado e Constituição. BOLZAN DE MORAIS, Jose Luis (Dir.). n. 11.), p. 70. 
como uma esfera pública heterônoma disciplinadora dos poderes selvagens do mercado e de proteção das gerações presentes e futuras.

Por outro lado, Ferrajoli entendia necessário o desenvolvimento de um constitucionalismo de direito internacional, uma vez que a afetação dos direitos e bens fundamentais assumiram um caráter planetário. Ao abordar o tema da soberania no mundo moderno, Ferrajoli58 já destacava a hipótese de um "totus orbis - de la humanidad como punto de referencia unificador en lugar de los viejos Estados", a qual, hoje, é passível de realização por meio da elaboração "de um constitucionalismo mundial capaz de atribuir a las diferentes cartas de derechos fundamentales, de las que dispone ya la comunidad internacional, aquellas garantías jurídicas cuya ausencia genera inefectividad." 0 jurista italiano, aqui, alerta para o fato de que não está pensando, em absoluto, em um improvável e não desejável governo mundial, mas sim em algo muito mais simples: "uma efectiva limitación de la soberanía de los Estados mediante el establecimiento de garantías jurisdiccionales contra las violaciones de la paz en el exterior y de los derechos humanos en el interior”59.

Evidente que a emergência destas novas esferas do constitucionalismo exigiriam o reconhecimento de novas autoridades de garantia ${ }^{60}$. Essa proposta, ainda carente de solidificação teórica, parece não prescindir da ideia de compatibilização de liberdade e segurança, tema com o qual se ocupa o tópico que segue.

\section{A NECESSIDADE DE COMPATIBILIZAR LIBERDADE E SEGURANÇA}

Tomando em consideração a questão aqui posta, neste contexto de emergência sanitária, interessa pôr em pauta, na seção final deste estudo em tudo preliminar, aquilo que Mireille Delmas-Marty ${ }^{61}$ propõe-se a responder, particularmente em termos de direito internacional: como retomar o fôlego da sociedade, desencantada com a vida e vinculada ao medo?

Trata-se de questão que assume especial relevância em um momento que parece ser expressão máxima da conjugação de “desencanto" e “medo". Na discussão suscitada pelos

\footnotetext{
${ }^{58}$ FERRAJOLI, Luigi. Derechos y garantías: la ley del más débil. Tradução de Perfecto Andrés Ibáñez e Andrea Greppi. Madri: Trotta, 2010, p. 152.

${ }^{59}$ FERRAJOLI, Luigi. Derechos y garantías: la ley del más débil. Tradução de Perfecto Andrés Ibáñez e Andrea Greppi. Madri: Trotta, 2010, p. 153.

${ }^{60}$ FERRAJOLI, Luigi. Por uma teoria dos direitos e dos bens fundamentais. Porto Alegre: Livraria do Advogado. 2011 (Coleção Estado e Constituição. BOLZAN DE MORAIS, Jose Luis (Dir.). n. 11.).

${ }^{61}$ DELMAS-MARTY, Mireille. Aux quatre vents du monde: petit guide de navigation sur l'océan de la mondialisation. Paris: Éditions du Seuil, 2016.
} 


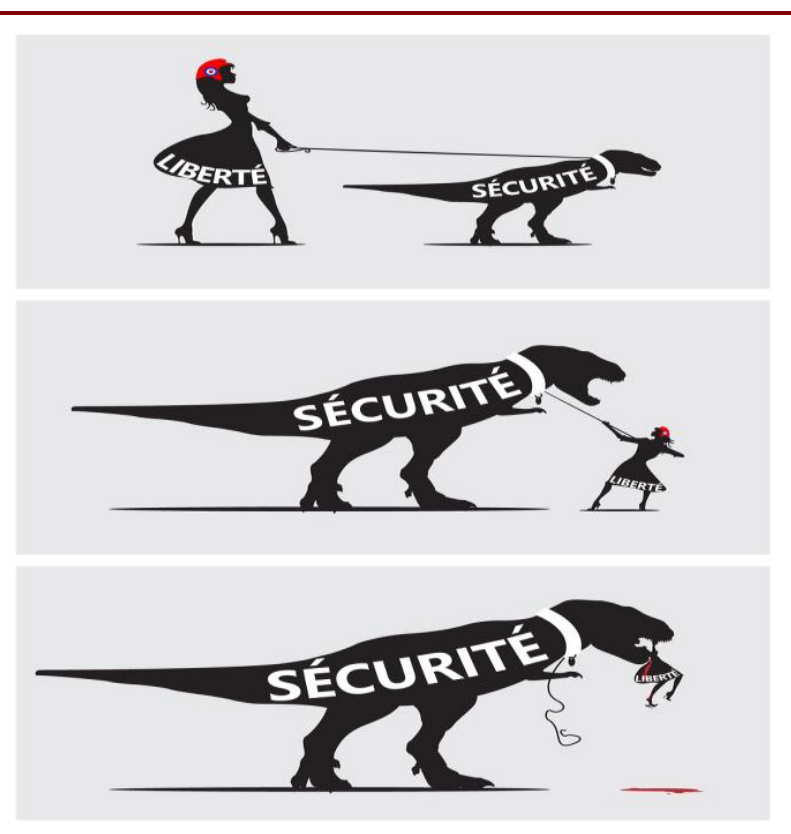

diversos teóricos cujas recentes abordagens do tema da pandemia desfilaram ao longo deste artigo, a tensão liberdade versus segurança, tal qual a charge ${ }^{62}$ a seguir, desponta como grande ponto de tensão relacionado ao tema do novo coronavírus, a exigir respostas que, ao que tudo indica, não poderão ser dadas a partir das categorias jurídico-políticas tradicionais.

Em ensaio instigante, Delmas-Marty procura meios de retomar esse importante motor para uma sociedade melhor, em tempos de desastres humanitários decorrentes das migrações, do terrorismo global, dos desastres ambientais, das crises financeiras e globais - e a Covid-19, parece conjugar todos (!) - que nos mostra, enquanto indivíduos, ser mais conveniente "ligar o motor automático" e seguir adiante, deixando a reação aos líderes e governantes. Tudo isso representa uma situação denominada por Ost $^{63}$ de "tempo de paragem", quer dizer, um momento no qual "aquilo que domina é a perspectiva de manter direitos adquiridos". Quando isso ocorre, segue o sobredito autor, "é porque mudamos de sociedade" e "já não se luta para que o futuro seja melhor", mas "apenas para que não seja pior".

Habermas $^{64}$, a propósito, refere o surgimento de uma crise do pensamento utópico, cuja função seria expor alternativas de ação e possibilidades de jogo que transcendam as continuidades históricas. Com efeito, na contemporaneidade as energias utópicas aparentam ter se esgotado, como se elas tivessem se retirado do pensamento histórico. Dessa forma, o horizonte do futuro se apequena e o espírito da época, assim como a política, mudam fundamentalmente. O futuro é marcado pelo pessimismo: vislumbra-se o panorama temível do perigo planetário de aniquilação dos interesses vitais gerais, a espiral da corrida armamentista, a difusão incontrolada de armas atômicas, o empobrecimento estrutural dos países subdesenvolvidos, as crescentes desigualdades sociais nos países desenvolvidos, os problemas da

\footnotetext{
62 Disponível em: https://www.reddit.com/r/france/comments/2zogrl/cest_pour_votre_bien . Acesso em: 21 mar. 2020.

63 OST, François. 0 tempo do Direito. Lisboa: Instituto Piaget, 1999, p. 340.

${ }^{64}$ HABERMAS, Jürgen. La crisis del Estado de bienestar y el agotamiento de las energías utópicas. In. HABERMAS, Jürgen. Ensayos políticos. Barcelona: Ediciones Península, 1988, p. 113-134.
} 
contaminação do meio-ambiente e as altas tecnologias que operam à beira contínua da catástrofe são os signos que marcam a pauta que, por meio da mídia de massa, chegam à consciência do público.

A metáfora dos "quatro ventos do mundo", utilizada por Delmas-Marty ${ }^{65}$ no título de seu ensaio, serve para indagar sobre o fenômeno da globalização e seus efeitos diferenciados em cada um dos "ventos" do mundo. A partir de uma perspectiva dinâmica da globalização, e na busca por processos que visam a humanizá-la, a jurista francesa propõe: 1) resistir à desumanização; 2) responsabilizar os atores e; 3) antecipar os riscos.

Parte, para tanto, da constatação de que muita coisa aconteceu desde o final da guerra fria: atentados terroristas, crises financeiras, deterioração do meio ambiente, crises migratórias, bem como integração regional, comunidades supranacionais e instituições que visam a melhor gerir a interdependência social e econômica advindas da globalização - e, agora, incluiríamos a crise global da Covid-19 e a emergência sanitária que lhe acompanha.

Não se pode deixar surpreender, portanto, com a desestabilização e, por vezes, com a ineficiência das políticas da governança global que foram idealizadas. Os ventos contrários fazem parte da globalização e são desafios para retomar o fôlego. Como uma "rosa dos ventos"66, Delmas-Marty ${ }^{67}$ associa a sua proposta a quatro "ventos dominantes", que são a liberdade, a segurança, a competição e a cooperação. Ela observa, em relação a estes "ventos", tensões do tipo: a) liberdade contra segurança; b) competição contra cooperação; c) inovação contra preservação e; d) exclusão contra integração. Essas tensões colocam, então, a seguinte questão: como reencontrar o equilíbrio, retomando o fôlego?

${ }^{65}$ DELMAS-MARTY, Mireille. Aux quatre vents du monde: petit guide de navigation sur l'océan de la mondialisation. Paris: Éditions du Seuil, 2016.

66 Reprodução da "ronde des vents" da obra de Delmas-Marty encontra-se disponível em: <https://recit38.wordpress.com/2017/12/31/manifeste-pour-une-mondialite-apaisee/>. Acesso em: 22 mar. 2020.

67 DELMAS-MARTY, Mireille. Aux quatre vents du monde: petit guide de navigation sur l'océan de la mondialisation. Paris: Éditions du Seuil, 2016. 
O fôlego, bem como o equilíbrio para que os ventos fluam em direção à compatibilidade é um desafio - talvez muito bem personificado pela pandemia do novo coronavírus. Isso porque os ventos contrários atuam em nível estatal e em nível das organizações e instituições internacionais. Um exemplo é o do terrorismo sem fronteiras que ganhou, junto à temática ambiental, enorme reconhecimento, por sua intensidade de ocorrência e amplitude particularmente a partir dos eventos de 11 de setembro - o que pode e deverá ser repetido agora a partir da Covid-19.

A respeito do terrorismo sem fronteiras a autora questiona a "substituição" do "estado de direito" pelo "estado do medo", mostrando a impotência dos governos em evitar os atentados terroristas, que são verdadeiros crimes globais, cujos responsáveis deveriam ter sido submetidos a uma jurisdição global, em uma corte penal internacional. Porém, com a resposta dos Estados Unidos aos atentados ao World Trade Center, evidenciou-se uma política de exceção, unilateral, com a edição do Patriotic Act - utilizado por Agamben $^{68}$ como exemplo para ilustrar suas teses sobre o "transbordamento" do estado de exceção na contemporaneidade - e a guerra ao terror que até hoje deixa muitas vítimas, questionando sua eficácia. No Direito Internacional, o Conselho de Segurança das Nações Unidas faz menção ao terrorismo como um ato de agressão, o que de certa maneira coloca em status de legítima defesa

ENTRER DANS LA RONDE DES VENTS

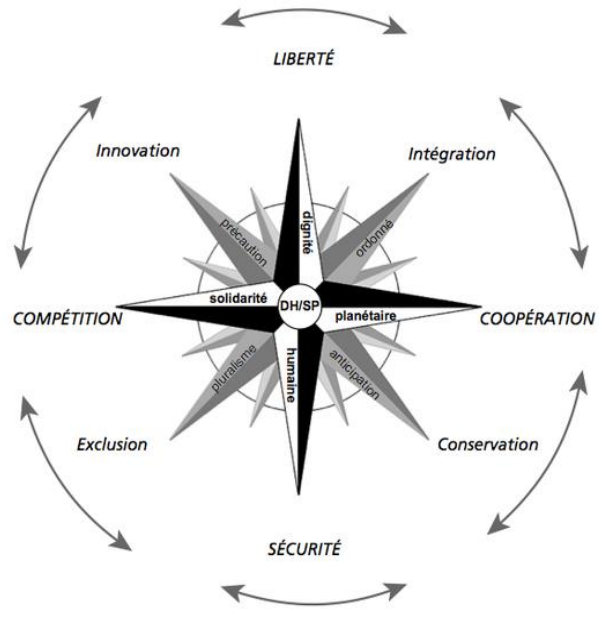
as políticas usadas pelos Estados Unidos na guerra ao terror ${ }^{69}$.

A indagação de Delmas-Marty ${ }^{70}$ é de com quem poderia ser feito um acordo de paz em relação ao terrorismo? Qual a "voz" do terrorismo? O Estado Islâmico? Outro questionamento da autora - que a aproxima da perspectiva de Ferrajoli no que pertine à crítica ao sistema onusiano abordada no tópico precedente - diz respeito a quem faria este acordo valer e o garantiria, dado que uma governança global com este objetivo ainda não existe.

\footnotetext{
${ }^{68}$ AGAMBEN, Giorgio. Estado de exceção. Tradução de Iraci Poletti. Rio de Janeiro: Boitempo, 2004.

69 DELMAS-MARTY, Mireille. Aux quatre vents du monde: petit guide de navigation sur l'océan de la mondialisation. Paris: Éditions du Seuil, 2016.

70 DELMAS-MARTY, Mireille. Aux quatre vents du monde: petit guide de navigation sur l'océan de la mondialisation. Paris: Éditions du Seuil, 2016.
} 
A metáfora da "rosa dos ventos", então, serve para orientar e tentar entender a dinâmica da direção dos ventos no processo da globalização, em busca de uma maior estabilidade na difícil tarefa da governança mundial. Nesse sentido, o argumento da autora é de que o terrorismo global é o “choque” entre os ventos da segurança e da liberdade enquanto que na política climática são os ventos da cooperação e competição que estão em "choque"71.

Em relação ao tema do novo coronavírus, poderíamos pensar, a partir da metáfora da jurista francesa, em um verdadeiro “torvelinho" entre esses quatro ventos, cujo caráter devastador ainda é cedo para mensurar, mesmo que sinais apontem para um cenário catastrófico em vários níveis, mesmo que, pelo menos momentaneamente, a tensão entre liberdade e segurança estejam dominando o debate, como transparece a partir das interpretações agambenianas acerca da crise sanitária e das políticas postas em ação.

A partir da proposta de Delmas-Marty ${ }^{72}$, o espírito da segurança deveria ser substituído pelo da garantia, do direito. Ela parte, para isso, da ideia de que o medo é necessário para a sobrevivência humana, e medidas vigilantes se fazem necessárias. Ocorre que, ao extremo, sociedades derivadas apenas ou maximizadamente do medo e da insegurança se tornam exemplos de busca por segurança que nunca resulta em paz - tal como ilustra a charge escolhida para apresentar esta discussão.

Por seu turno, o espirito da inovação se situa na rosa dos ventos entre a competição e a liberdade. Inovar é cortar as amarras que distanciam do progresso. Por este ponto, é libertar-se. Nesse sentido, a autora questiona sobre a autorização destas inovações, que vão desde exploração do gás de xisto e de produção de organismos geneticamente modificados até, num futuro não muito distante, clonagem humana e robôs humanos. Esta autorização é questionada do mesmo modo quanto aos limites da liberdade e da competição ${ }^{73}$.

0 espirito da conservação está posicionado em direção oposta ao da inovação, sendo percebido às vezes como inação ou regressão, e em se tratando da conservação da natureza é algo menos dinâmico/interativo ao espírito da preservação da natureza. A inovação pode ser usada como meio para atingir o progresso, bem a proteção do clima, quando é utilizada para

\footnotetext{
71 DELMAS-MARTY, Mireille. Aux quatre vents du monde: petit guide de navigation sur l'océan de la mondialisation. Paris: Éditions du Seuil, 2016.

72 DELMAS-MARTY, Mireille. Aux quatre vents du monde: petit guide de navigation sur l'océan de la mondialisation. Paris: Éditions du Seuil, 2016.

73 DELMAS-MARTY, Mireille. Aux quatre vents du monde: petit guide de navigation sur l'océan de la mondialisation. Paris: Éditions du Seuil, 2016.
} 
medir e prever estratégias de ação e adaptação/atenuação das consequências do aumento da temperatura do planeta, causados pela espécie humana ${ }^{74}$.

O espírito da integração, situado na rosa dos ventos entre a cooperação e a liberdade, retorna ao espírito de fraternidade, privilegiando as forças de atração e não de repulsão. A ação individual em prol de valores comuns da humanidade que, colocados em prática na política, faz parte deste espírito de integração (seja nas políticas de migrações ou de justiça social), promove uma inserção social justa. A questão cultural também merece nota, uma vez que muitas culturas são reprimidas em nome de uma só que represente a identidade nacional; a integração busca maior diversidade e, portanto, é plural. A união europeia e o cidadão europeu podem ser um exemplo desta mistura cultural. Não é exemplo, porém, em se tratando da resposta que a União Europeia tem oferecido às migrações, violando um princípio de hospitalidade universal. Com efeito, a exclusão é o oposto da integração, e está posicionada entre a segurança e a competição.

A respeito do "sopro dos ventos", a hipótese de Delmas-Marty ${ }^{75}$ é de que a globalização não deve ser suavizada com o triunfo de um só vento dominante: a segurança sem liberdade pode desencadear regimes totalitários; a liberdade sem segurança pode criar o caos; a competição sem cooperação pode conduzir a conflitos; e a cooperação sem competição é um fôlego frequentemente ineficaz. A inovação sem conservação pode levar a rupturas indesejadas, mas a conservação sem a inovação pode paralisar; exclusão sem integração gera conflito, mas a integração sem exclusão dificilmente logra êxito.

A governança global, guiada pela administração dos ventos, contribui para o reequilíbrio das tensões provocadas pela globalização. Assim, em conexão com outra obra de Delmas-Marty (2004), é possível pensar em quatro princípios que, dentro da proposta do presente artigo, podem ser pensados como condição de possibilidade para dar concretude à proposta de Ferrajoli de uma “Constituição planetária”. Isso porque esses quatro princípios contribuem, na teoria de Delmas-Marty, para promover o esperado “equilíbrio entre os ventos”. São eles: 1) a segurança e a liberdade sendo guiadas pelo princípio de igual dignidade a todos os seres humanos; 2) a competição e cooperação sobre o princípio da solidariedade planetária; 3) a inovação e a conservação sobre o princípio da precaução-antecipação e; 4) a exclusão e integração sobre o princípio do pluralismo ordenado.

\footnotetext{
${ }^{74}$ DELMAS-MARTY, Mireille. Aux quatre vents du monde: petit guide de navigation sur l'océan de la mondialisation. Paris: Éditions du Seuil, 2016.

75 DELMAS-MARTY, Mireille. Aux quatre vents du monde: petit guide de navigation sur l'océan de la mondialisation. Paris: Éditions du Seuil, 2016, p. 81.
} 
DA EXCEÇÃO AGAMBENIANA À CONSTITUIÇÃO PLANETÁRIA DE FERRAJOLI: DESAFIOS IMPOSTOS PELA PANDEMIA DO NOVO CORONAVÍRUS ÀS CATEGORIAS JURÍDICO-POLÍTICAS TRADICIONAIS

MAIQUEL ÂNGELO DEZORDI WERMUTH JOSÉ LUIS BOLZAN DE MORAIS

A começar pelo princípio da dignidade humana, pode-se encontrar uma condição de possibilidade para que estados de emergência não destruam ou coloquem em risco a liberdade dos cidadãos em nome da segurança ${ }^{76}$. 0 princípio da solidariedade planetária é violado como reflexo da incoerência da globalização em não saber lidar com as mudanças dos ventos, deixando de reconhecer, por exemplo, a existência de bens comuns ${ }^{77}$ - como aqueles que a proposta de Ferrajoli acerca de uma "Constituição planetária" toma como ponto de partida. 0 princípio da precaução/antecipação propõe-se enquanto um equilíbrio entre a inovação e a conservação e pode ser associado ao desenvolvimento sustentável quando diz respeito às gerações futuras, dilatando o efeito das ações que tomamos como espécie humana do presente em relação às gerações futuras. Por fim, o princípio do pluralismo ordenado se posiciona para melhor guiar o espírito de exclusão e de integração, seja em escala nacional, regional ou global por uma perspectiva pluralista e universal que admita diversidades mas que permaneçam em compatibilidade aos objetivos comuns. Em se tratando das diversidades culturais, o princípio do pluralismo ordenado busca a aproximação cultural ${ }^{78}$.

Do exposto, torna-se possível asseverar que novas categorias jurídicas como as ideias de "gerações futuras" e "bens públicos mundiais" - a ideia do "comum" -auxiliam nesta tentativa de aprimoramento do direito internacional - quiçá rumo à "Constituição da Terra" almejada por Ferrajoli.

76 Sobre o assunto, reportagem publicada no sítio espanhol “Público" alerta, em reportagem de 21 de
março de 2020 , para a utilização do estado de emergência como ferramenta policial para aplicação
desmedida de multas na Espanha: até a sexta-feira, dia 20 de março, 315 pessoas haviam sido detidas;
somente na Comunidade de Madri já se contabilizavam mais de 7.500 multas aplicadas. A reportagem está
disponível em: https://www.publico.es/politica/crisis-coronavirus-ley-mordaza-herramienta-policial-
aplicar-miles-multasalarma.html?utm_source=whatsapp\&utm_medium=social\&utm_campaign=web. Acesso
em: 22 mar. 2020.
77 De acordo com Monbiot, “um bem comum é um recurso sobre o qual uma comunidade tem direitos
iguais e compartilhados. A princípio, esta noção poderia incluir a terra, água, minerais, conhecimento,
pesquisa científica e software. Mas, no momento, a maior parte destes recursos tem sido cercada:
confiscados tanto pelo Estado quanto pelos interesses privados e tratados como qualquer outra forma de
capital. Através deste cercamento, nós temos sido privados da nossa riqueza comum." Nesse sentido, "A
restauração dos bens comuns tem um grande potencial não apenas de distribuir a riqueza, mas também de
mudar a sociedade. [...] um bem comum não é apenas um recurso (terra, árvores ou software) mas
também é a comunidade de pessoas que o gerencia e protege. Aqueles que participam da gestão e
usufruto dos bens comuns desenvolvem conexóes muito mais profundas entre si e com os seus recursos do
que nós, enquanto consumidores passivos de produtos corporativos." MONBIOT, George. Bens Comuns,
antídoto ao Neoliberalismo. Tradução de Gabriel Simões. Instituto Humanitas UNISINOS, 13 jan. 2017.
Disponível em: http://www.ihu.unisinos.br/186-noticias/noticias-2017/563941-bens-comuns-antidoto-ao-
neoliberalismo . Acesso em: 21 mar. 2020 . ${ }_{78}$ DELMAS-MARTY, Mireille. Le Relatif et l'Universel: Les Forces Imaginantes du Droit, vol. I, Seuil, Paris, 2004. 


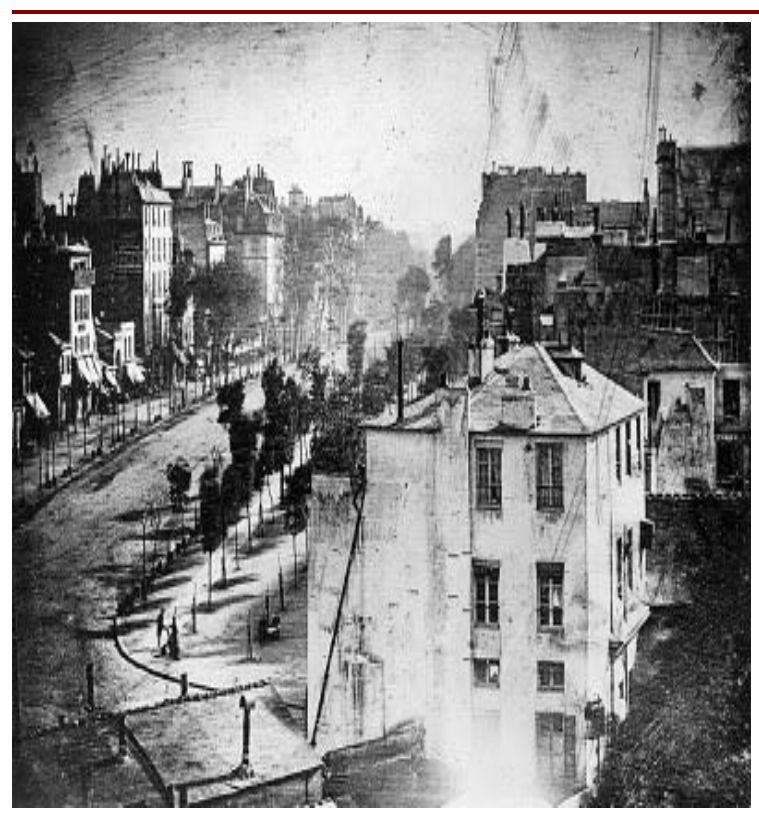

Paralelamente a isso, o reconhecimento da interdependência de todos os atores mundiais em prol de objetivos comuns - tal como o Diretor-Geral da OMS nos convoca a pensar alternativas à pandemia do novo coronavírus - é, indubitavelmente - e, parece, diante da emergência sanitária atual, inexoravelmente - um destino comum.

\section{CONSIDERAÇÕES FINAIS: PARA NÃO CONCLUIR...}

Retomando o autor que nos deu o mote para estas primeiras reflexões sobre os efeitos da pandemia do novo coronavírus sobre as categorias jurídico-políticas tradicionais, no ensaio $O$ dia do juízo, Agamben ${ }^{79}$ reflete sobre a fotografia como "o lugar do Juízo Universal”, uma vez que ela representa, a seu ver, "o mundo assim como aparece no último dia, no Dia da Cólera."

A partir da fotografia intitulada Boulevard Du Temple ${ }^{80}$, o autor justifica sua reflexão: tida como a primeira fotografia a representar uma figura humana, trata-se de um daguerreótipo no qual aparece a figura de um homem apenas, em um horário de pico no qual o boulevard em questão deveria estar cheio de carroças e pessoas. Apenas ele aparece, em virtude do fato de que ficou imóvel o tempo suficiente - enquanto engraxava os sapatos - para que o aparelho utilizado por Daguerre conseguisse capturá-lo, pois era necessário um tempo de exposição muito longo.

Essa fotografia sugere, para Agamben ${ }^{81}$, a imagem perfeita do Juízo Final: “a multidão de humanos - aliás, a humanidade inteira - está presente, mas não se vê, pois o juízo refere-se a uma só pessoa, a uma só vida: exatamente àquela, e não a outra." 0 fato de o homem que

\footnotetext{
${ }^{79}$ AGAMBEN, Giorgio. Profanações. Trad. Selvino J. Assmann. São Paulo: Boitempo, 2007, p. 27.

80 Disponível em: https://oglobo.globo.com/sociedade/historia/conheca-primeira-fotografia-ondeaparece-um-ser-humano-14468103 . Acesso em: 21 mar. 2020.

${ }^{81}$ AGAMBEN, Giorgio. Profanações. Trad. Selvino J. Assmann. São Paulo: Boitempo, 2007, p. 28.
} 
aparece na foto estar no momento de um gesto banal - engraxar os sapatos - faz o autor afirmar que "no instante supremo, o homem, cada homem, fica entregue para sempre a seu gesto mais ínfimo e cotidiano."82

A reflexão de Agamben parece-nos, ao final deste estudo, apropriada para evidenciar aquilo que a pandemia do novo coronavírus expôs ao mundo: nossa solidão no meio da multidão e, ao mesmo tempo, nossa profunda conexão com essa mesma multidão - o caráter político de nossos corpos.

As diferentes respostas teóricas aqui abordadas são, todas elas, ainda perfunctórias, mas possuem, em comum, a preocupação com o fato de que a atual situação de emergência sanitária em nível planetário representa um momento de ruptura que exigirá respostas para além das categorias tradicionais.

Por isso mesmo, para o campo jurídico-político são postas interrogações que vão desde a revisão crítica de todo um tempo de neoliberalismo predominante que marcou a disputa entre os avanços de um modelo, ainda liberal, de Estado Social, explicitado no constitucionalismo Pós-II Guerra Mundial, bem como nos processos de (re)democratização tanto europeia e latinoamericana, esta a partir da década de 1980, e a tentativa da escola hayekiana de refundação de um liberalismo clássico alicerçado em um capitalismo de cassino, como nomeado por Avelãs Nunes, passando pela emergência de uma transformação profunda nos espaços, atores e formas de atuação dos poderes, agora não mais centrados na figura leviatânica do Estado Nação soberano.

Neste contexto, depois da crise ambiental e das novas experiências do terror já no século XXI, a crise sanitária da Covid-19 parece estar a exigir que não mais deixemos escoar o tempo para a construção de um novo projeto civilizatório, que leve em consideração esta transição paradigmática que agora nos bate mais fortemente à porta, enquanto a maioria da humanidade encontra-se fechada em suas casas - pelo menos aqueles cujas casas ainda sobraram após a última grande crise da economia capitalista de cassino, em 2008.

Sem isso, uma nova ou a próxima pandemia talvez no encontre ainda mais fragilizados para o seu enfrentamento.

Quem viver, verá! No mais, lavemos as mãos e fiquemos em casa! Valorizemos o SUS e a pesquisa!

${ }^{82}$ AGAMBEN, Giorgio. Profanações. Trad. Selvino J. Assmann. São Paulo: Boitempo, 2007, p. 28. 


\section{REFERÊNCIAS}

AGAMBEN, Giorgio. Estado de exceção. Tradução de Iraci Poletti. Rio de Janeiro: Boitempo, 2004.

AGAMBEN, Giorgio. Profanações. Trad. Selvino J. Assmann. São Paulo: Boitempo, 2007.

AGAMBEN, Giorgio. O estado de exceção provocado por uma emergência imotivada. Tradução de Luisa Rabolini. Instituto Humanitas UNISINOS, 26 fev. 2020a. Disponível em:

http://www.ihu.unisinos.br/78-noticias/596584-o-estado-de-excecao-provocado-por-umaemergencia-imotivada. Acesso em: 18 mar. 2020.

AGAMBEN, Giorgio. Contagio. Quodlibet, 11 mar. 2020b. Disponível em:

https://www.quodlibet.it/giorgio-agamben-contagio . Acesso em: 18 mar. 2020.

AGAMBEN, Giorgio. Chiarimenti. Quodlibet, 17 mar. 2020c. Disponível em:

https://www.quodlibet.it/giorgio-agamben-chiarimenti . Acesso em: 18 mar. 2020.

AVELÃS NUNES, António José. O estado capitalista em tempos de globalização. 2012.

Conferência inaugural do Congresso Internacional sobre "Defesa do Estado e Garantia dos Direitos do Cidadão em Tempos de Crise: os Desafios da Advocacia de Estado - Intercâmbio Brasil/Itália". Disponível em: https://www.fd.uc.pt/ anunes/pdfs/conf_8.pdf . Acesso em: 19 mar. 2020.

DELMAS-MARTY, Mireille. Aux quatre vents du monde: petit guide de navigation sur l'océan de la mondialisation. Paris: Éditions du Seuil, 2016.

DELMAS-MARTY, Mireille. Le Relatif et l'Universel: Les Forces Imaginantes du Droit, vol. I, Seuil, Paris, 2004.

DE MASI, Domenico. Coronavírus anuncia revolução no modo de vida que conhecemos. Folha de São Paulo, 22 mar. 2020. Disponível em:

https: / / www1.folha.uol.com.br/ilustrissima/2020/03/coronavirus-anuncia-revolucao-no-modode-vida-que-conhecemos.shtml . Acesso em: 22 mar. 2020.

FERRAJOLI, Luigi. Derechos y garantías: la ley del más débil. Tradução de Perfecto Andrés Ibáñez e Andrea Greppi. Madri: Trotta, 2010, p. 152.

FERRAJOLI, Luigi. Por uma teoria dos direitos e dos bens fundamentais. Porto Alegre: Livraria do Advogado. 2011 (Coleção Estado e Constituição. BOLZAN DE MORAIS, Jose Luis (Dir.). n. 11.).

FERRAJOLI, Luigi. A democracia através dos direitos: o constitucionalismo garantista como modelo téorico e como projeto político. Tradução de Alexander Araújo de Souza e outros. São Paulo: Revista dos Tribunais, 2015. 
FERRAJOLI, Luigi. O vírus põe a globalização de joelhos. Tradução de Moisés Sbardelotto. Instituto Humanitas UNISINOS, 18 mar. 2020. Disponível em: http://www. ihu.unisinos.br/78noticias/597204-o-virus-poe-a-globalizacao-de-joelhos-artigo-de-luigi-ferrajoli . Acesso em: 19 mar. 2020.

HABERMAS, Jürgen. La crisis del Estado de bienestar y el agotamiento de las energías utópicas. In. HABERMAS, Jürgen. Ensayos políticos. Barcelona: Ediciones Península, 1988, p. 113-134.

HARARI, Yuval Noah. In the Battle Against Coronavirus, Humanity Lacks Leadership. Time, 15 mar. 2020. Disponível em: https://time.com/5803225/yuval-noah-harari-coronavirus-humanityleadership Acesso em: 20 mar. 2020.

HARDT, Michael; NEGRI, Antonio. Multidão: guerra e democracia na Era do Império. Rio de Janeiro: Record, 2005.

LA VALLE, Raniero. Por uma escola e uma constituição da Terra. Tradução de Moisés Sbardelotto. Instituto Humanitas UNISINOS, 18 dez. 2019. Disponível em: http://www.ihu.unisinos.br/595259. Acesso em: 19 mar. 2020.

LIDDELL, H.G.; SCOTT, R. A greek-english /exicort. 9. ed., Oxford: Claredon Press, 1983.

MARCOVECCHIO, E. Dizionario etimológico storico dei íermini mediei. Firenze: Festina Lente, 1993.

MONBIOT, George. Bens Comuns, antídoto ao Neoliberalismo. Tradução de Gabriel Simões. Instituto Humanitas UNISINOS, 13 jan. 2017. Disponível em: http://www.ihu.unisinos.br/186noticias/noticias-2017/563941-bens-comuns-antidoto-ao-neoliberalismo . Acesso em: 21 mar. 2020.

OST, François. 0 tempo do Direito. Lisboa: Instituto Piaget, 1999.

PÉREZ TAPIAS, José Antonio. Entre o risco e o medo, a biopolítica em alta. Instituto Humanitas UNISINOS, 17 mar. 2020. Disponível em: http://www.ihu.unisinos.br/78-noticias/597147-entreo-risco-e-o-medo-a-biopolitica-em-alta Acesso em: 19 mar. 2020.

REZENDE, Joffre Marcondes de. Epidemia, endemia, pandemia. Epidemiologia. Revista de Patologia Tropical, vol. 27, n. 1, p 153-155, 1998.

RODRIGUES, Bruno Cava. Democracia biopolítica. Instituto Humanitas UNISINOS, 15 mar. 2020. Disponível em: http://www.ihu.unisinos.br/597085-democracia-biopolitica. Acesso em: 19 mar. 2020.

ROTH, André-Noël. O Direito em crise: fim do Estado Moderno? In. FARIA, José Eduardo. Direito e globalização econômica: implicações e perspectivas. São Paulo: Malheiros, p. 15-27, 2010.

VENTURA, Deisy de Freitas Lima; AITH, Fernando Mussa Abujamra; RACHED, Danielle Hanna. A emergência do novo coronavírus e a "lei de quarentena" no Brasil. Revista Direito e Práxis, Ahead of print, Rio de Janeiro, 2020. Disponível em: https://www.epublicacoes.uerj.br/index.php/revistaceaju/article/view/49180. Acesso em: 21 mar. 2020. 
DA EXCEÇÃO AGAMBENIANA À CONSTITUIÇÃO PLANETÁRIA DE FERRAJOLI: DESAFIOS IMPOSTOS PELA PANDEMIA DO NOVO CORONAVÍRUS ÀS CATEGORIAS JURÍDICO-POLÍTICAS

VENTURA, Deisy de Freitas Lima. "Temos que ir pelo caminho de grande investimento público para a proteção das pessoas". O Povo on line, 18 mar. 2020. Disponível em: https: //www.opovo.com.br/coronavirus/2020/03/18/temos-que-ir-pelo-caminho-de-grandeinvestimento-publico-para-a-protecao-das-pessoas.html. Acesso em: 21 mar. 2020.

\author{
ŽlŽEK, Slavoj. Monitorar e punir? Sim, por favor! Tradução de Leonardo Mendonça. Tradutores \\ proletários, 16 mar. 2020. Disponível em: \\ https: / /tradutoresproletarios.wordpress.com/2020/03/17/zizek-monitorar-e-punir-sim-por- \\ favor. Acesso em: 18 mar. 2020.
}

Recebido em: 23.03.2020 / Revisões requeridas em: 30.03.2020 / Aprovado em: 01.04.2020 / Publicado em: 01.04.2020

\title{
COMO FAZER REFERÊNCIA AO ARTIGO (ABNT):
}

WERMUTHM, Maiquel Ângelo Dezordi; BOLZAN DE MORAIS, Jose Luis. Da exceção Agambeniana à constituição planetária de Ferrajoli: desafios impostos pela pandemia do novo coronavírus às categorias jurídico-políticas tradicionais. Revista Eletrônica do Curso de Direito da UFSM, Santa Maria, RS, v. 15, n. 1, e43057, jan./abr. 2020. ISSN 1981-3694. DOI: http://dx.doi.org/10.5902/1981369443057. Disponível em: https://periodicos.ufsm.br/revistadireito/article/view/43057 Acesso em: dia mês. ano.

Direitos autorais 2020 Revista Eletrônica do Curso de Direito da UFSM

Editores responsáveis: Rafael Santos de Oliveira e Angela Araujo da Silveira Espindola

Esta obra está licenciada com uma Licença Creative Commons Atribuição-NãoComercial-SemDerivações 4.0 Internacional.

\section{SOBRE OS AUTORES}

\section{MAIQUEL ÂNGELO DEZORDI WERMUTH}

Doutor em Direito pela Universidade do Vale do Rio dos Sinos - UNISINOS (2014). Mestre em Direito pela UNISINOS (2010). Pósgraduado em Direito Penal e Direito Processual Penal pela Universidade Regional do Noroeste do Estado do Rio Grande do Sul - UNIJUÍ (2008). Graduado em Direito pela UNIJUÍ (2006). Coordenador do Programa de Pós-Graduação Stricto Sensu (Mestrado e Doutorado) em Direito da UNIJUÍ. Professor-pesquisador do Programa de Pós-graduação em Direito da UNIJUÍ. Professor dos Cursos de Graduação em Direito da UNIJUÍ e da UNISINOS. Coordenador da Rede de Pesquisa Direitos Humanos e Políticas Públicas (REDIHPP) e líder do Grupo de Pesquisa Biopolítica e Direitos Humanos (CNPq).

\section{JOSE LUIS BOLZAN DE MORAIS}

Possui graduação em Direito pela Universidade Federal de Santa Maria (1984), mestrado em Direito pela Pontifícia Universidade Católica do Rio de Janeiro (1989), doutorado em Direito pela Universidade Federal de Santa Catarina (1995), com estágio "sanduíche" na Universidade de Montpellier I - França e Pós-Doutoramento junto à Faculdade de Direito da Universidade de Coimbra. Foi professor da pós-graduação da Universidade do Vale do Rio dos Sinos (1997-2018). Atualmente é professor do PPGDireito da Faculdade de Direito de Vitória- FDV, da Universidade de Itaúna e da Escola superior Dom Helder Câmara. Procurador do Estado do Estado do Rio Grande do Sul junto aos Tribunais Superiores (STF/STJ). Membro do conselho consultivo do Instituto de Hermenêutica Jurídica, Consultor ad hoc da CAPES, CNPQ, FAPERGS, FAPESC, FAPEMIG e Università degli studi di Roma Tre. Professor convidado da pós-graduação - Universita de Firenze, Universita Roma I, Universidad de Sevilla e Universidade de Coimbra. Coordenador do Grupo de Pesquisa Estado \& Constituição (CNPq) (GEPE\&C) e da Rede de Pesquisa Estado \& Constituição (REPE\&C). Pesquisador PQ/CNPq. Foi membro do Grupo de Especialistas para a Reforma da legislação de migrações do MJ/SNJ. Membro da CNEJ/CFOAB (2013/2015) e Vice-Presidente Acadêmico da Comissão de Mediação e Práticas Restaurativas da OAB/RS, até 2018. Tem experiência na área de Direito, com ênfase em Teoria do Estado e Direito Constitucional, atuando principalmente nos seguintes temas: constituição, estado, direito, jurisdição e direitos humanos. E experiência administrativa acadêmica como diretor de curso de graduação e de pósgraduação (mestrado e doutorado), bem como de gestão universitária. 